e-mail: irynasultanova@gmail.com

https://orcid.org/00-0003-2298-359X

Iванишин Iрина Мирославівна - кандидат хіміч- $:$ Ivanyshyn Iryna Myroslavivna - Candidate of них наук, доцент, ДВНЗ “Прикарпатський націо- Science (Chemistry), Associate Professor (Ph. D.), нальний університет імені Василя Стефаника" Vasyl Stefanyk Precarpathian National University (Івано-Франківськ, Україна) (Ivano-Frankivsk, Ukraine)

e-mail: Iraivan68@gmail.com https://orcid.org/0000-0003-1765-8311

Арламовський Родіон Васильович- кандидат наук Arlamovskyi Rodion Vasylovych - Candidate of з фізичного виховання та спорту, ДВНЗ “Прикар- Science (Physical Education and Sport), Vasyl Stefaпатський національний університет імені Василя nyk Precarpathian National University (IvanoСтефаника" (Івано-Франківськ, Україна) https://orcid.org/0000-0002-8778-2476

Фірка Анна Миколаївна - магістр, ДВНЗ “Прикарпатський національний університет імені Василя Стефаника" (Івано-Франківськ, Україна)

\title{
ДИНАМІКА СПОРТИВНОГО РУХУ В РУМУНІї, ПОВ'ЯЗАНА З ЕЛЕМЕНТАМИ УПРАВЛІННЯ ТА МАРКЕТИНГУ В СПОРТІ
}

Мета. Встановити динаміку спортивного руху в Румунї в контексті управління та маркетингу в спорті. Методи. Здійснюючи дослідження ми виходили з гіпотези, щуо різке зменшення кількості клубів та числа спортсменів є наслідком відсутності управлінських та маркетингових стратегій. Для отримання результатів були використані матеріали Національного інституту статистики. Результати. Дослідження спрямоване на вивчення еволюиї спортивних федерачій, спортивних клубів та зростання кількості спортсменів в Румунії (1992-2017 рр.). Аналіз даних статистики вказує на те, щуо еволючійні зміни вище зазначених утворень залежав від специфіки виду спорту та відповідних періодів суспільно-політичного розвитку держави (відразу після зміни політичної системи - 1992 р. та майже два десятиліття після - 2017 р.). Особливо важливу роль у збільшенні кількості спортивних клубів $і$ числа практикуючих спортсменів відіграли національні федерачії, які фінансувалися Міністерством молоді та спорту. Висновок. Встановлено, що маркетинг у XXI столітті є важливим фактором як для розвитку спортивної інфраструктури, так і для залучення молоді до занять спортом.

Ключові слова: спортивні федерачії, спортивні клуби, спортсмени, фінансування, спортивне управління та маркетинг, соџіальна політика.

The purpose of the study to establish the dynamics of sports movement in Romania in the context of management and marketing in sports. Methods. The study started from the hypothesis that the drastic decrease in the number of clubs and legitimate people is a consequence of the lack of management and marketing strategies. Materials from the National Institute of Statistics were used to obtain the resultsi. Results. The research is aimed at the evolution of the sports phenomenon, characterized by the number of sports federations, sports clubs and athletes legitimated between 1992 and 2017. Although statistics show a different dynamic from one type of sport to another, the study makes a comparison between the two periods: immediately after the change of the political system (1992) and almost two decades after (2017). The research started from the hypothesis that the type of management and marketing applied at the federation level, as a national structure under the Ministry of Youth and Sports and funded from a single source, influenced the number of clubs and, implicitly, the number of practitioners. The data were collected from the National Institute of Statistics of Romania, from the Ministry of Sports. The conclusions of the study present some correlations between the evolution of diffe- 
rent federations. Conclusion. It has been established that marketing in the 21 st century is an important factor both for the development of sports infrastructure and for attracting young people to sports.

Keywords: sports federations, sports clubs, athletes, funding, sports management and marketing, social policy.

Introduction. From an etymological point of view, the current concept of management comes from the Latin word "manus" (hand), meaning "manoeuvring". In English, the verb "to manage" with the noun "management" appeared with the initial meaning of "to handle" and then with the meaning of "properly reason the relationships with various things or finites in order to obtain a proper result" [17]. Management is the organizational function that ensures the efficient development of activities and which aims to achieve the maximum level of results through the optimal use of resources. The management activity can consider groups of people (teams) or processes.

The resources that a manager has, mainly, available: time, talent, financial resources and human resources [15].

Management is also the name given to the team of managers within an organization. In the interwar period, the general concept of marketing appears in the American business environment and in sports it appeared in 1971 in football where it enjoyed a real success, expanding rapidly to other sports passing through white sports and now reaching eSports which grows exponentially from one year to another [11]. Life-long development and continuous academic studies have led to effective concepts and principles with amazing results. In the general sense, marketing is "the science and art of convincing customers to buy" [4]. Baker M. defined marketing as "a social and managerial process by which individuals or groups of individuals obtain what they need and want by creating, offering and exchanging products and services a certain value." Applied in sports, this concept would translate into "convincing people that practicing sports has immediate benefits" [1]. Due to the characteristics of marketing processes, to the ways of implementing marketing decisions, to the new meanings and visions on the elements that make up a marketing action and as a result of different levels of perception and approach to this component of the market economy, the definitions and explanations of the marketing term are varied and constantly adapted to the new realities of the economic environment.

The definition was revised again in 2004 and describes marketing as "an organizational function and set of processes designed to create, communicate and make available to customers the value and maintenance of customer relationships for the benefit of the company and its owners" [12].

In his original publications, Philip Kotler defines: "Marketing is an activity designed to meet the needs and desires through processes of change" [12]. A response from the "Chartered Institute of Marketing" (CIM) can be added to Kotler and Norris' definitions. The association's definition states that marketing is "the managerial process of anticipating, identifying and satisfying customer requirements in a profitable way". Therefore, operational marketing includes the processes of marketing analysis, development of a new product, management of the life cycle of a product, pricing, management of the distribution channel and promotions.

The purpose of the study to establish the dynamics of sports movement in Romania in the context of management and marketing in sports.

Methods. The study started from the hypothesis that the drastic decrease in the number of clubs and legitimate people is a consequence of the lack of management and marketing strategies. Materials from the National Institute of Statistics were used to obtain the results.

Results. We find that in Romania, according to the National Institute of Statistics, which publishes a clear record between 1992 and 2017, regarding the number of sports 
federations, the number of sports clubs and legitimate athletes decreases alarmingly from one year to another [18].

It is certain that in 1992 in Romania a number of 379,482 athletes were legitimized at the level of all sports federations, while in 2017 there were 111,317 athletes (fig. 1). This is a reduction of about 3.4 times [18]. This reduction is based on a decrease in the number of practitioners over the age of 20 . Until that period, there were many working-class sports clubs, which belonged to economic companies and were subsidized by them. At the time of liberalization and transition to a market economy, the first staff reductions or the reduction of subsidies until the cancellation thereof were those directed to own sports associations. This has led in an overwhelming percentage to the dissolution of workers' sports associations.

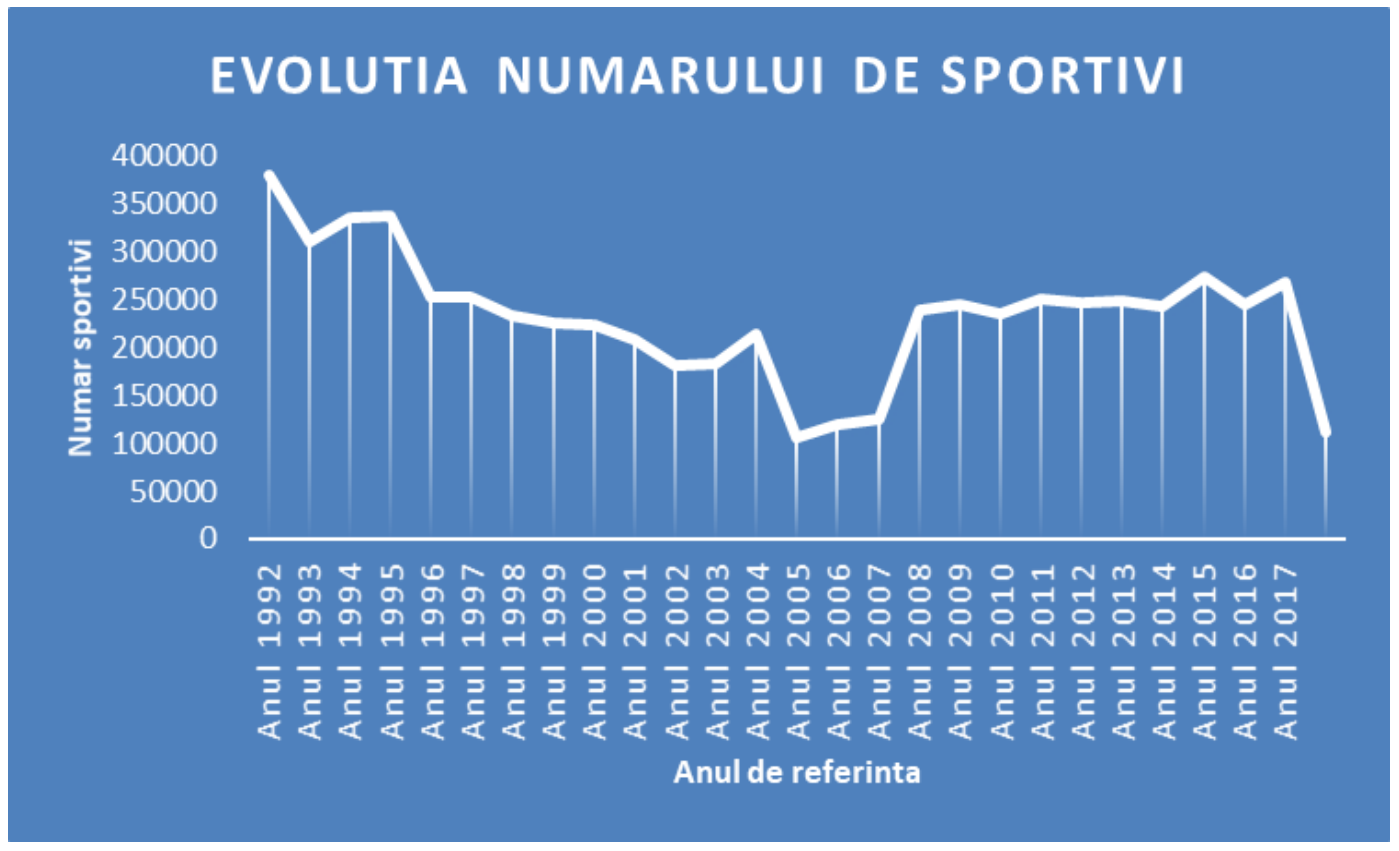

Fig. 1. Evolution of the number of athletes

Regarding the number of federations, there is an increase from 49 to 82 , which represents an increase by 1.6 times (chart no. 2). From the 82 sports federations we find that in 26 the number of athletes has increased and in 56 the number of athletes has decreased, so we see that in some branches of sports, such as football, basketball, athletics, karate, motorcycling, sport dancing, the number of practitioners increases from one year to another, the most spectacular increase being found in basketball which recorded an increase from 1992 to 2017 by 22,293 athletes and in others such as handball, chess, boxing, bodybuilding, weightlifting, bowling, radio amateurs, rugby, table tennis, the number of athletes decreases, as handball records the biggest loss with 57,210 athletes from 1992 to 2017.

On the other hand, an analysis of the emergence of fitness centres (as a mass sports) shows that they grew after 2000 and an accelerated development after 2010 when the major fitness centre operators (World Class) appeared on the Romanian market [23]. Thus, this increase in the number of fitness centres could provide an explanation for the transition of a segment of the population from performance sports to mass sports.

A possible explanation for the increase in the number of athletes in some federations is that they operate and promote a multidisciplinary approach to the sports phenomenon, including the "liberalization" of practice. This represents the possibility for clubs to impose a fee for each practitioner. Although apparently a mandatory element, which underlies the opera- 
tion of an institution that provides services, this would require some notions of management and marketing such as: conducting a market study on competition; providing quality services through the staff employed and through the material conditions; developing a promotion strategy; judicious administration of resources, etc.

From the analysis of the activities of the federations (fig. 2) which showed an increase in the number of athletes, training actions of instructors and coaches in sports management and marketing were identified [19].

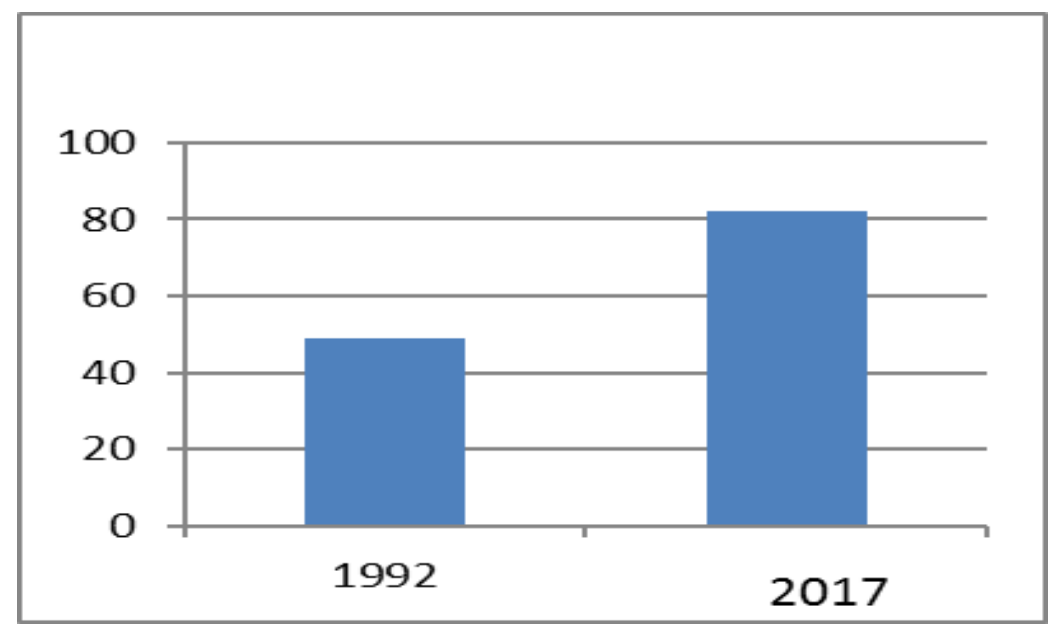

Fig. 2. Evolution of the number of federations

From the point of view of the dynamics of the number of clubs (fig. 3) there is an inconsistent evolution in different periods, but which were interpreted in parallel with the economic situation. Thus, during the 1990s, there was a steady decline until 1999, amid a disastrous evolution of the national economy and implicitly the social welfare of the population. Following the emergence of the law on the status of clubs and sports associations in the private sector, there has been an increase in the number of clubs since 2007, which are mostly sources of income for administrators [20]. This is also due to the fact that even though the number of clubs has started to increase, the number of athletes has decreased in recent years. We believe that this phenomenon is based on the increase in the number of sports clubs that address mass sports and less performance sports.

Compared to other countries where the education to exercise starts early [22], such as the Nordic countries, the percentage of people who exercise is $90 \%$, in countries that assign particular importance to sport such as England, Germany, France, Austria, Switzerland the percentage is of about $77 \%$ and at the opposite end there are the countries that do not pay special attention to such education, countries such as Romania, Bulgaria, where the percentage is below 30\% ranking on the last two places in the EU according to Eurostat published in 2017 for a study from 2015, although the Romanian specialized newspapers and even the Ministry of Youth and Sports publish in the "National Strategy for Sports 20142028 " report that Romania would have a percentage of $40 \%$ [19]. 


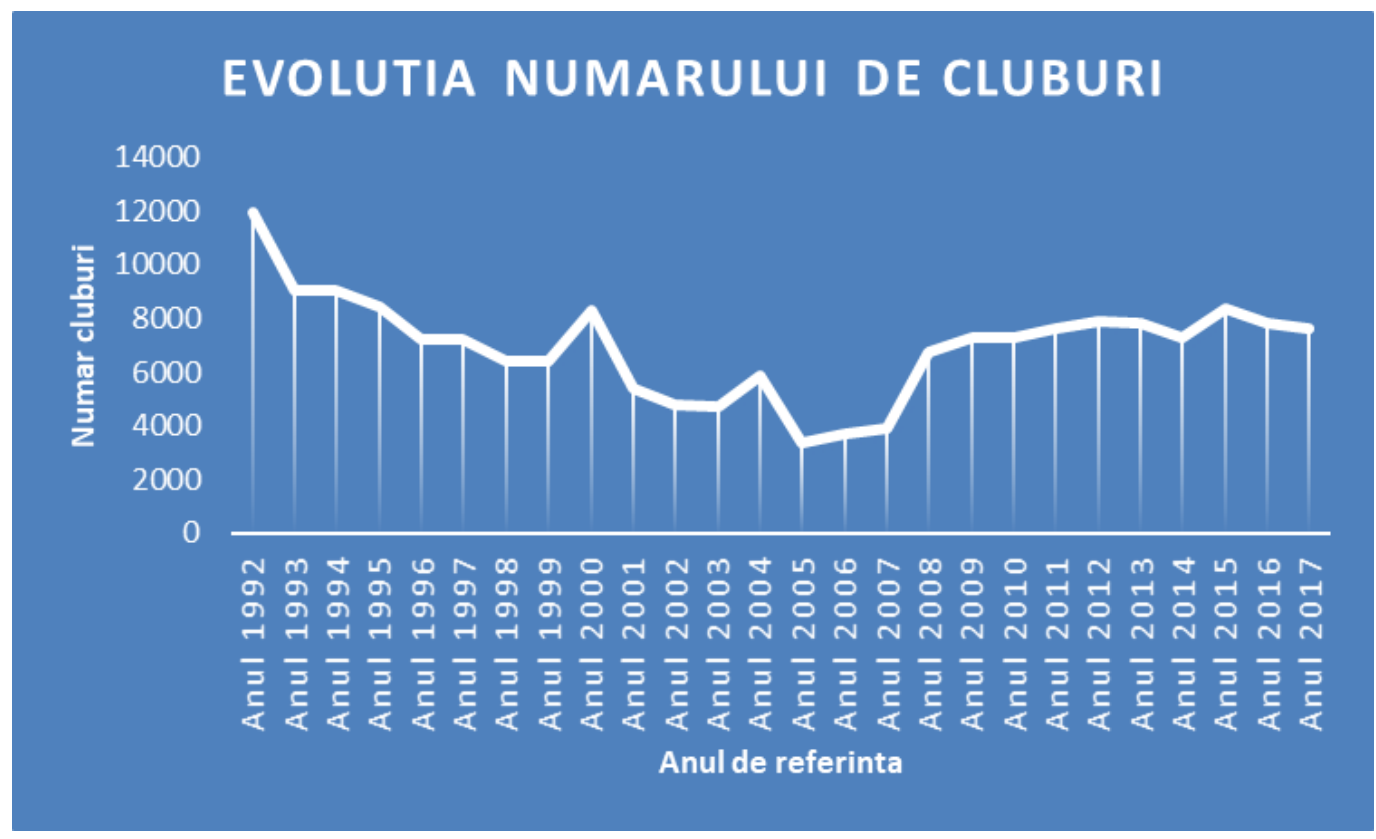

Fig. 3. Evolution of the number of clubs

\section{Conclusions.}

1. In the current context, the research is part, by topic and content, from a study of the individual's behaviour on the practice of exercise and also of the involvement of the policy in terms of spending budget allocations in order to meet the main objective of making sports.

2. Also, where there are sportsmen involved in marketing strategies, we see that the number of athletes is growing. The best example is the Romanian Basketball Federation where in 1992 there were 5015 athletes and in 2017 they reached 27308 athletes and gyms that have known an accelerated development according to the articles from Ziarul Financiar and Prosport newspaper that say: "Fitness centres represent an official business of 160 million lei on the local market, in the last ten years the evolution being a spectacular one, given that the number of companies operating in this sector grew from 277 companies in 2008 to just over 1,100 companies in 2017, according to an analysis of ZF, based on data from the Trade Register [23].

3. The turnover reported by the companies operating on NACE code "activities of fitness centres" increased from only 17 million lei in 2008 to 162 million lei in 2017, namely ten times, according to ZF calculations. The data also show that 1,900 employees worked in the field of sports centres in 2017, as compared to only 445 employees of companies operating fitness centres ten years ago, according to the same source [23]. This shows us how important marketing is in attracting people to exercise as the evolution of $21^{\text {st }}$ century technology and internet has certainly brought about consistent or even radical changes in terms of practicing physical exercises in any form.

\section{References}

1. Aaron CT. Introduction to Sport Marketing, Hungary: Butterworth Heinemann, imprimare a Elsevier LTD. 2008. ISBN: 978-0-7506-8685-3.

2. Alexsandru LM. The strategic sport marketing Planning Process, Manager Journal [online]. 2013; 17: 230-236.

3. Allaire Y., Firsirotu M. Management Strategic, Ed. Economica. 1988.

4. Baker M. Marketing-an introductory text, sixth edition, Ed. Macmilllan. 1996.

5. Best R. Market based management, Ed. Pretince Hall. 2005.

6. Borza A. Management strategic si competitivitate in afaceri, Ed. Dacia 2003. 
7. Balaure V. Marketing, ediţia a II-a revăzută şi adăugită, Edit. Uranus, Bucureşti, 2002.

8. Coman P. Bază de date cu agenţii de marketing şi management sportiv worldwide. 2016.

9. Conway DG. The Event Manager's Bible: The complete guide to planning and organising a voluntary or public event, revised and updated third edition. Oxford UK: How To Books Ltd. 2009.

10. DeGaris L. Sport Marketing Consulting Strategies and Tactics: Bridging the Academy and the Practice. 2008.

11. Gherasim T., Gherasim A. Cercetări de marketing, Edit. Economică, Bucureşti. 2003.

12. Kotler P., Armsrong G., Cunningham MH. Principles of marketing. Toronto, Pearson Prentice Hall. 2005.

13. Lazar I., Veres V., Mortan M., Lazar SP. Management general, Edit. Risoprint, Cluj-Napoca. 2004.

14. Macra-Os0rheam M., Purdea D. Managementul resurselor umane - motivare, carieră, recompense, Edit. Dacia, Cluj-Napoca. 2006.

15. Mihailescu N. Management, Marketing, Legislaţie în activitatea sportivă, Edit. Universităţii din Piteşti. 2006.

16. Oprisan V. Marketing şi comunicare în sport, Edit. Uranus, Bucureşti. 2001.

17. Voicu AV. Managementul organizaţiilor şi activităţii sportive, Edit. Risoprint, ClujNapoca. 1998.

18. http://statistici.insse.ro:8077/tempo-online/\#/pages/tables/insse-table.

19. http://mts.ro/wp-content/uploads/2016/02/Strategia-nationala-pentru-SPORT-_1_.pdf.

20. http://mts.ro/acte-normative-in-vigoare.

21. https://ec.europa.eu/eurostat/documents/4031688/8716412/KS-07-17-123-EN-N.pdf/908e0e7fa416-48a9-8fb7-d874f4950f57.

22. https://appsso.eurostat.ec.europa.eu/nui/show.do?query=BOOKMARK_DS-812530_QID_772C666F_UID.

23. https://www.zf.ro/companii/piata-centrelor-de-fitness.

\title{
Цитування на цю статтю:
}

Корнеліу Мірон, Чіразі Марін. Динаміка спортивного руху в румунії, пов’язана з елементами управління та маркетингу в спорті. Вісник Прикарпатського університету. Серія: Фізична культура. 2020 Листоп 03; 35: 59-64

\begin{tabular}{|c|c|}
\hline Відомості про автора: & Information about the author: \\
\hline $\begin{array}{l}\text { Чіразі Марін - доктор філософських наук, пр- } \\
\text { офесор, Університет Олександру Іоан Куза (Ясси, } \\
\text { Румунія) }\end{array}$ & $\begin{array}{l}\text { Chirazi Marin - Doctor of Philosophical Sciences, } \\
\text { Professor, Universitatea Alexandru Ioan Cuza (Iaşi, } \\
\text { Romania). }\end{array}$ \\
\hline
\end{tabular}

\section{УДК 796.07+159.942 doi: 10.15330/fcult.35.64-78}

\section{Зіновій Остап'як, Богдан Мицкан,Тетяна Мицкан, Ігор Випасняк, Мар'яна Лесів}

\section{ЕМОЦЙНИЙ ІНТЕЛЕКТ І СПОРТ}

\begin{abstract}
Актуальність. Змагальний характер спорту та стресові умови викликають у кожного спортсмена різні емоції, які можуть вплинути на спортивні показники і кожен вид спорту має особливі фізичні, технічні характеристики, які потребують спеціальних навичок для спортсменів. Великий обсяг досліджень підкреслив важливість емоиійного інтелекту для прогнозу у всіх сферах життя. Отжже,і не дивно, щзо інтерес до емоиійного інтелекту в спорті також суттєво виріс. Мета. Аналіз впливу занять спортом на розвиток емоційного інтелекту, його особливості в спортсменів різних видів спорту та у тренерів. Методи. Для реалізації поставленої мети використані теоретичні методи: аналіз, синтез, індукція, дедукція. Результати. Був виявлений значний зв'язок між фізичною активністю і різними компонентами емочійного інтелекту у дітей, підлітків та у студентів. Вік і стать є ключовими модераторами цьього зв'язку: за ознакою статі - дівчатка володіють більшим емочійним інтелектом, ніж хлопчики. Аналіз показників емоційного інтелекту у спортсменів показав певні відмінності рівня
\end{abstract}

